Mahmut Kaya, Felsefe ve Ölüm Ötesi (İbn Sînâ, Gazzâlî, İbn Rüşd, Fahreddîn Râzî),

(Klasik, İstanbul, 2013, 149 sayfa.)

Tarihsel süreç içerisinde birçok dinde ahiret inancının varlığını gösteren pek çok bulguya rastlanmaktadır. Örneğin eski Mısırlılar, mumyalanmış soylularını değerli eşyalarıyla birlikte tanrı Osiris'in heykelleriyle mezarlara gömerken, Hindular yeniden bedenlenmeden, Budistler ise yeniden doğumdan bahsetmektedir. Öte yandan Kur'an'da ahiret kelimesi yüz on beş yerde tekrar edilmesinin yanı sıra yeniden diriliş, hesaba çekilme, cennet ve cehennem konularına değinilmektedir. İnsanlar genellikle ahiret hayatının varlığını kabul etseler de ölüm ve ötesi hakkında detaylı bir bilgiye sahip değildirler. Bu nedenle ahiret hayatının mahiyeti, yeniden bedenlenme, ruhun dirilmesi ve nefsin ebediliği gibi problemlere din başta olmak üzere felsefe, tıp, edebiyat ve psikoloji gibi disiplinler çözüm üretmeye çalışmaktadır. Dinin bu problemlere getirdiği çözümlerle beraber felsefenin de çabası yadsınamayacak derecede önem arz etmektedir. İşte tam da bu noktada Mahmut Kaya'nın Felsefe ve Ölüm Ötesi adlı eseri bu çabanın bir gereği olarak ortaya çıkmıştır.

İslam felsefesinin klasiklerini tercüme etmesiyle bilinen ve İslam düşüncesi üzerinde birçok eseri kaleme alan Mahmut Kaya, Felsefe ve Ölüm Ötesi adlı çalışmasında da İslam düşüncesinin önemli şahsiyetlerinden İbn Sînâ, Gazzâlî, İbn Rüşd ve Fahreddîn Râzî'nin ölüm hakkındaki felsefi görüşlerini derlemiştir. Kaya, bunun yanı sıra Paul Janet ve Gabriel Sêailles'nin ilkçağ ve modern çă̆ filozoflarının ölüm ve ötesine ilişkin fikirlerini kapsayan çalışmalarını da eserin ek kısmında bizlere sunmuştur.

Her bir filozofun kitaplarında konuya ilişkin kısımların çevirisini içeren bu eser beş bölümden müteşekkildir. Kaya, eserde adı geçen filozofların eserlerinden bazı bölümlerin doğrudan tercümelerini yapmaktadır. Ayrıca Kaya, İbn Sînâ'nın Ruh Kasidesi eserinin tercümesine ek olarak kendisine ait bir şiirle eserde kendi etkisini göstermektedir. İncelenen eserde filozofların kitaplarından seçilen bölümlerin ele alınan konuyla bir bütünlük içerisinde, akıcı ve anlaşılır bir üslupla sunulması eseri daha da önemli kılmaktadır. Eserin birinci bölümü İbn Sînâ'nın el-Adhaviyye fi'l-me'âd, eş-Şifâ/el-İlâhîyyât: ahiret hakkında ve Ruh Kasidesi eserlerinin ölüm ve ötesi bağlamındaki 
içeriğinden oluşmaktadır. Yazar, İbn Sînâ'nın bu eserlerinde ahiret konusunda geçmişteki toplulukların sahip olduğu ruh ve bedenin ahiretteki durumu, ruh göçünün imkânsızlığı ve nefs gibi konuları kapsayan metinlerin tercümelerini sunmaktadır (s.1-67).

Kaya, Gazzâlî́nin Tehâfütü'l-felâsife adlı çalışmasına eserin ikinci bölümünde yer vermektedir. Burada müellif, bedenlerin dirilişi, ruhların bedenlere iadesi, cennet, huriler ve benzeri hususlarda filozofların konuyu sembolik bir bağlamda ele alması noktasında Gazzâlî́nin eleştirilerine değinmektedir. Bu bağlamda yazar, filozofların ahiretin sadece akılla bilinebileceği görüşünün aksine Gazzâlî́nin nefsin ölümsüzlüğü kabul edilmeden ahiretin anlaşılamayacağını savunduğunu da aktarmaktadır (s.6884).

Eserin üçüncü bölümünde ise Kaya, İbn Rüşd'ün Tehâfütü't-Tehâfüt ve el-Keşf 'an menâhici'l edile fì akâidi'l-mille eserlerine yer vermektedir. Yazar, İbn Rüşd'ün bedenlerin dirilişi ve dinin gerekliliği hususlarında Gazzâlî́ye yaptığı tenkitlerin yanı sıra filozofların tutumuna ilişkin izahlarına değinmektedir. Bu minvalde müellif, Gazzâlî́nin filozofların bedenin dirilişini inkar ettiklerini söylemesine İbn Rüşd'ün karşı çıtığını ve filozofların bu görüşte olmadıklarına ilişkin açıklamalarını nakletmektedir (s.85-88). Öte yandan Kaya, İbn Rüşd'ün el-Keşf 'an menâhici'l edile fì akâidi'l-mille'de ise dinlerin ahiretin varlığı konusunda ittifak ettiğine ulemanın (filozofların) da deliller öne sürdüğüne dair düşüncelerini aktarmaktadır. Buna bağlı olarak müellif, İbn Rüşd'ün dinlerin ahiretin nasıl gerçekleşeceği konusunda ihtilaf ettiklerini bu nedenle de bazı dinlerde yeniden dirilmenin sadece ruhsal olacağı öngörülürken, bazılarının da beden ve ruh birlikteliği ile gerçekleşeceğini savunduğuna değinmektedir. Bu doğrultuda Kaya, İbn Rüşd'ün nefsin ölümsüzlüğünün mümkün olup olmadığına yönelik yaptığı izahlarını da sunmaktadır (s.91-97).

Kaya, Fahreddin er-Râzînnin el-Metâlibu'l-âliye mine'l-ilmi'l-ilâhi isimli eserinin ölüm ve ötesine ilişkin kısımlarına, çalışmasının dördüncü bölümünde yer vermektedir. Râzî́nin ölüm sonrasında nefsin hayatiyetini devam ettirdiğine ilişkin pasajına dikkat çeken Kaya, onun bu iddiasını ikna yöntemiyle savunduğunu zikretmektedir (s.98-119). Benzer şekilde Râzî́nin bedene taalluk eden duyusal hazların ötesinde akli hazların varlığına işaret 
ettiğini ve bu hazların ahiret hayatıyla ilişkisine temas ettiğini aktarmaktadır (s.120-124).

Kaya, eserin son bölümü olan ek kısminda Paul Janet ve Gabriel Sêailles tarafından kaleme alınan Histoire de la philosophie: lesproblêmes et lesêcoles adlı eserin Elmalılı Hamdi Yazır tarafından yapılan çevirisine yer vermektedir. Elmalı'nın Tahlilî Tarih-î Felsefe: Metâlib ve Mezâhib adıyla yaptığ1 tercümesinde ahiret sorununun tartışıldığı "Matlab-1 Hayât-1 Ahiret" başlıklı üçüncü bölümü aktaran müellif, böylece batı düşünce geleneğinde ahiret söyleminin seyri noktasında okura bilgi vermektedir (s.126-145). Bu açıdan İslam düşüncesinde tartışılan ahiret konusunun Batı düşünce dünyasındaki yansımalarını görebilmek ve değerlendirebilmek bu bölüme ayrı bir önem kazandirmaktadır.

Kaya'nın Felsefe ve Ölüm Ötesi adlı çalışması İslam düşüncesinin önemli simalarının ahiret, ölüm ve ötesi ve nefs gibi konulara ilişkin felsefi görüşlerine işaret eden metinlerinden ve bunların çevirilerinden oluşmaktadır. $\mathrm{Bu}$ eser, ahiret ve ölüm konusunda neler söylendiğini merak eden ve felsefe alanında çalışma yapan akademisyenlere ve konuya ilgi duyan okur kitlesine hitap etmektedir.

\section{Menci Tekin}

Mardin Artuklu Üniversitesi Sosyal Bilimler Enstitüsü Felsefe ve Din Bilimleri Anabilim Dalı Yüksek Lisans Öğrencisi 